\title{
EFFECTIVENESS OF COMPLETE BLOOD COUNT PARAMETERS FOR PREDICTING INTRACRANIAL INJURY IN CHILDREN WITH MINOR HEAD TRAUMA
}

\author{
Berksoy Atas Emel, An1l Murat \\ Health Science University, Tepecik Education and training Hospital, \\ Pediatric Emergency Clinic, İzmir, Turkey
}

Primljen/Received 31. 01. 2019. god.

Abstract: Objective: We aimed to investigate the relationship between trauma severity and platelet indices (PI) and white blood cell (WBC) count to identify traumatic brain injury (TBI) in children with minor head trauma (MHT). Materials and methods: This prospective study included children with acute isolated MHT who underwent head computed tomography (CT) based on Pediatric Emergency Care Research Network (PECARN) criteria. Mean platelet volume (MPV), platelet distribution width (PDW), MPV to platelet ratio (MPV/PL), MPV to white blood cell ratio (MPV/WBC), and MPV to Neutrophil ratio (MPV/Neu) were evaluated.

Results: 86 children with MHT and 245 controls were included the study. WBC, Neu count, MPV, MPV/WBC, MPV/Neu and MPV/PI ratios were statistically different among patients with abnormal $\mathrm{CT}$, patients with normal $\mathrm{CT}$ and healthy controls $(\mathrm{p}<0.05)$. For predicting abbreviated injury score (AIS) $>1$, the AUC values of WBC, neutrophil, MPV/WBC and MPV/Neu were $0.746,0.739,0.726$ and 0.724 , respectively.

Conclusion: In children with MHT who underwent CT, WBC, Neu counts, MPV/WBC and MPV/Neu ratios may be helpful for predicting the severity of trauma in pediatric emergency department.

Key words: children; complete blood count; head trauma; intracranial injury.

\section{INTRODUCTION}

Isolated minor head trauma (MHT) is a common cause of presentation at the paediatric emergency room, and includes the majority of all head trauma patients admitted to the paediatric emergency service. The most important mission of the clinician in the management of patients with MHT is to detect serious trauma-
Prihvaćen/Accepted 08. 03. 2019. god.

tic brain injury (TBI), which is estimated to represent one-third of all injury-related deaths (1). The most appropriate imaging technique for diagnosing TBI is head computed tomography (CT). Significant TBI is detected in $<1 \%$ of patients with MHT (1). In clinical practice we use The Paediatric Emergency Care Applied Research Network (PECARN) validated rule to identify children with MHT at very low risk for significant TBI without a head CT scan (2). Nevertheless, paediatric emergency physicians frequently face difficulties making a decision due to exaggerated concerns and insistent attitudes of parents, and usually disagree with neurosurgeons about requests for control head CT scans to detect possible TBI. While an unnecessary CT scan can lead to excessive radiation exposure and costs, bypassing a CT scan despite the insistence of the family may result in missing TBI.

Trauma acts as the trigger for a cascade of hemodynamic, metabolic, neuroendocrine, and immune responses leading to secondary tissue damage (3). Platelets, neutrophils, and lymphocytes are markers that reflect the inflammatory response which is required for subsequent restoration of homeostasis (4). Platelet count and platelet function are predictors of mortality, and the latter also contributes to detrimental cerebral bleeding in TBI $(5,6)$. The platelet volume indices (PVI) including mean platelet volume (MPV) and platelet distribution width (PDW) reflect the average size of platelets in the blood and correlate with platelet activity and function (7). These are parameters that can be derived inexpensively from a complete blood count (CBC). PVI and MPV have potential clinical utility, particularly in haematology and cardiovascular medicine $(8,9,10)$. Until now, the diagnostic performance of MPV, WBC, and platelet count for determining trau- 
ma severity and to identify TBI in patients with MHT have been investigated in few adult clinical studies (11, 12, 13).

To the best of our knowledge, no study has investigated CBC parameters in children with MHT; thus, we determined whether PVI and WBC count could be used as predictors of TBI in those patients. We researched how neutrophils, lymphocytes, platelets, and the PVI derived from a $\mathrm{CBC}$ result in changes in children with MHT; and if these parameters are useful to predict TBI.

\section{MATERIAL AND METHODS}

This prospective study was performed in patients with MHT who were admitted to the paediatric emergency and trauma centre of our university hospital between March and July 2017 with approval of the Ethical Committee of Katip Çelebi University. Patients with MHT were characterized as having a Glascow Coma Score (GCS) of 14 or 15, no abnormal findings on a neurological examination, and no signs of basilar skull fracture such as hemotympanum, oto- or rhinorrhoea, or a periocular or posterior auricular hematoma. The management of all patients and the head CT scan requirements were determined according to the PECARN guidelines. Unenhanced CT scans were performed on a 16-slice MX16 (Philips Medical Systems, Best, Netherlands) scanner with $1.5 \mathrm{~mm}$ slices of the cranial base and $2.5 \mathrm{~mm}$ for the brain parenchyma. Blood samples were drawn from every patient meeting the study criteria and who were willing to participate in the study within 10 min after they arrived in the emergency room. All head CT scans were evaluated by a neurosurgeon and a radiologist. The presence of a skull fracture (linear or depressed), acute epidural, subdural or parenchymal hematomas, subarachnoid haemorrhage, concussion, and cerebral oedema were considered positive CT results. Severe trauma was defined clinically by any of the following: admission to a ward for at least $48 \mathrm{~h}$, admission to a paediatric intensive care unit (PI$\mathrm{CU})$, patients needing intubation, increased intracranial pressure treatment, transfusion, and exitus. Intracranial injury in a CT-positive patient was assessed using the abbreviated injury score (AIS, 2005) and ranked on a scale of 1 to 6 , with 1 being minor and 6 being non survivable injury. The patient clinical and demographic characteristics (age, sex, vomiting, duration of loss of consciousness, presence of seizure or focal neurological deficit, presence of scalp hematoma and size, mechanism of trauma, and short outcome) were recorded. Patients whose GCS was $<14$; those who had multiple trauma, penetrating injuries, anaemia, chronic disease, acute or chronic infection, bleeding diathesis, soft tissue injury; and patients who were admitted $24 \mathrm{~h}$ after trauma were not included in the study. Eventually, 86 children with acute isolated MHT who underwent a head CT scan and presented to the paediatric emergency room were included in the study. The control group consisted of 245 healthy children who had no trauma, no soft tissue injury, and no infection history during the 3 months before admission for a CBC exam. Written informed consent was obtained from the guardians of each patient before blood was taken.

CBCs were performed using a Coulter analyser (LH-780; Beckman Coulter, Brea, CA, USA) with the impedance method (intra-assay variation coefficient $1.6 \%$, interassay variation coefficient $1.65 \%$ ), which was routinely checked every month in the central laboratory of our hospital. Standard tubes with a constant amount of K3-EDTA were used. Blood samples of each patient were examined within $15 \mathrm{~min}$ to avoid any possible variation in the PVI. The PVI included MPV, PDW, and plateletcrit. Furthermore, we examined other platelet indices calculated based on $\mathrm{CBC}$ : MPV/platelets (MPV/PL), MPV/WBC (MPV/W), and MPV/Neu $(\mathrm{MPV} / \mathrm{N})$.

The statistical analyses were performed with SPSS for Windows software (SPSS Inc., Chicago, IL, USA). Quantitative data are presented as median with interquartile range. The Kruskal-Wallis test was used to evaluate the differences between study groups (head CT-positive and CT-negative) and healthy group for continuous variables. Differences in the means of continuous variables between groups (head CT-positive and head CT-negative) were analysed with the Mann-Whitney $U$-test. Differences in categorical variables were analysed with the chi-square test. Spearman's correlation test was used to assess the associations between laboratory parameters and the AIS score. The predictive ability of the laboratory data for the trauma severity was evaluated with receiver operating characteristic analyses. A p-value < 0.05 was considered statistically significant.

\section{RESULTS}

Of the 86 patients with MHT who underwent a head CT scan based on the PECARN criteria, 27 females $(31.7 \%)$ and 59 males $(68.6 \%)$ were included in the study. The median age of the patients with MHT was 3 years ( 1 month to 17 years). The median age of the control group was 6 years $(1$ month to 17 years $)(p>0.05)$. A total of 8 patients $(9.3 \%)$ were injured by in-car accidents, $2(2.3 \%)$ were injured by out-of-car accidents, $26(30.2 \%)$ were injured by falling from a height, 1 $(1.1 \%)$ was injured by a motor vehicle accident, and 49 $(56.9 \%)$ were injured by low-energy impact. Sixty patients $(69.7 \%)$ were discharged after emergency service observation, and eighteen (20.9\%) were admitted to 
the neurosurgery clinic after initial treatment. Five patients $(5.8 \%)$ included in the study were in need of surgery, three patients $(3.4 \%)$ were in need of the PICU, and no patients died.

The evaluation of the head CT scans showed that 36 patients $(41.9 \%)$ had brain pathologies including skull fractures, whereas the head CT scans of 50 patients (58.1\%) were normal. Among the head CT scan-positive group, 20 had isolated skull fractures, 18 of which were linear and 2 that were depressed fractures. Thirteen patients $(15.1 \%)$ had intracranial haemorrhages (subdural or epidural hematomas). Of these patients, six had a linear skull fracture and one had a depressed skull fracture. Three of the patients $(3.5 \%)$ had contusions with a linear skull fracture on a head CT scan. The clinical and demographic characteristics of the patients are shown in Table 1 .

When we divided the cases into three groups based on the presence or absence on head CT scans and the control group, we found that WBC, Neu, MPV, $\mathrm{MPV} / \mathrm{PL}, \mathrm{MPV} / \mathrm{W}$, and MPV/N were significant variables (Table 2).

The WBC and Neu values increased progressively from the healthy controls $(8.5 / \mathrm{L}$ and $3.3 / \mathrm{L})$ to head CT-negative patients with MHT (10.4/L and 4.7/L), and further to patients with a head CT-positive scan $(12.2 / \mathrm{L}$ and $7.1 / \mathrm{L} ; \mathrm{p}<0.01)$. The MPV/W and MPV/N values decreased progressively from the healthy controls (1 and 2.5) to head CT-negative patients (0.74 and 1.5), and further to head CT-positive patients (0.64 and 1.16; $\mathrm{p}<0.01$ ) (Table 2). Significant differences were observed between patients who had clinically severe trauma and AIS scores $\geq 2$ and those with no severe trauma and AIS scores $<2$ in terms of WBC, Neu, MPV/W, and WBC/N (Table 3).

A negative correlation was detected between the AIS score and MPV/W $(\mathrm{r}=-0.282 ; \mathrm{p}<0.05)$ and MPV/N $(\mathrm{r}=$
Table 1. The clinical characteristics of the patients

\begin{tabular}{|l|l|}
\hline \multicolumn{2}{|l|}{ Patients n (\%) } \\
\hline Age (median, IOR) & $3(1-7)$ \\
\hline Sex (male/female) & $59 / 27(68.6 / 31.4)$ \\
\hline Symptoms/signs & \\
\hline Vomitting & \\
\hline$<3$ & $13(15.1)$ \\
\hline$\geq 3$ & $9(10.5)$ \\
\hline headache & $7(8.1)$ \\
\hline Loss of conciousness $>$ 5 sn & $7(8.1)$ \\
\hline seizure & $1(1.2)$ \\
\hline Frontal hematoma & $12(13.9)$ \\
\hline Occipital hematoma & $10(11.6)$ \\
\hline Parietal/temporal hematoma & $19(22)$ \\
\hline Clinically severe trauma + & $13(15.1)$ \\
\hline Mechanism of injury & \\
\hline fall from height & $26(30.2)$ \\
\hline low energy injury & $49(56.9)$ \\
\hline in car- accident & $8(9.3)$ \\
\hline out-car accident & $2(2.3)$ \\
\hline bike/motorcycle injury & $1(1.1)$ \\
\hline Head CT +/ head CT- & $36 / 50$ \\
\hline Isolated lineer / depressed fracture & $18 / 2$ \\
\hline lineer fracture + IC hemorrhage & 6 \\
\hline IC hemorrhage + depressed fracture & 1 \\
\hline Lineer fracture + contusion & 3 \\
\hline IC hemorrhage without skull fracture & 13 \\
\hline AIS score $\geq 2 /<2$ & $14 / 72(16.3 / 83.7)$ \\
\hline discharge from pediatric emergency room & $60(69.7)$ \\
\hline admission to the wards & $3(20.9)$ \\
\hline admission to PICU & \\
\hline underwent operation & \\
\hline
\end{tabular}

Table 2. Comparison of CBC markers in the study groups and control group

\begin{tabular}{|c|c|c|c|c|}
\hline & \multicolumn{2}{|c|}{ Study group (min-max) } & $\begin{array}{l}\text { Control group } \\
(\min -\max ))\end{array}$ & $\mathbf{p}$ \\
\hline Age (years) & \multicolumn{2}{|c|}{$3(1-7)$} & $6(1-7)$ & ,439 \\
\hline Sex (n) (female/male) & \multicolumn{2}{|c|}{$27 / 59$} & $69 / 186$ & \\
\hline & $\mathbf{C T}+$ & CT - & & \\
\hline WBC (/I) & $12.2(9.7-18.7)$ & $10.4(8.5-12,4)$ & $\mathbf{8 , 5}(7.1-10,9)$ & $<0,001^{\mathrm{a}, \mathrm{b}, \mathrm{c}}$ \\
\hline $\operatorname{Neu}(/ \mathrm{I})$ & $7.1(4.4-14.6)$ & $\mathbf{4 , 7}(2.9-6,3)$ & $3.3(2.5-4.4 .7)$ & $<0,001^{\mathrm{a}, \mathrm{b}, \mathrm{c}}$ \\
\hline Plt $\left(\mathrm{x} 10-^{3}\right)$ & $293(237-393)$ & $312.5(257.5-383.7)$ & $290(233.2-233.2)$ & 0,440 \\
\hline PDW & $16.4(16.3-16.7)$ & $16.4(16,1-16.7)$ & $16.5(16.1-17)$ & 0,607 \\
\hline Pct & ,25 (,20-,29) & ,24 (,20-,29) & ,24 (,20-,29) & 0,855 \\
\hline MPV (fl) & $7.7(7.3-8.6)$ & $7.6(7.2-8.1)$ & $8.4(8.1-9)$. & $<0,001^{\mathrm{a}, \mathrm{b}, \mathrm{c}}$ \\
\hline $\mathrm{MPV} / \mathrm{WBC}$ &, $64(, 42-, 85)$ &, $74(, 62-, 86)$ & $\mathbf{1}(, 78-1,2)$ & $<0,001^{\mathrm{a}, \mathrm{b}, \mathrm{c}}$ \\
\hline MPV/Neu & $\mathbf{1 , 1 6}(, 57-1,6)$ & $\mathbf{1 , 5}(1,2-2,6)$ & $2,5(1,8-3,4)$ & $<0,001^{\mathrm{a}, \mathrm{b}, \mathrm{c}}$ \\
\hline $\mathrm{MPV} / \mathrm{Pl}$ & ,026 (,018-,035) & $024(, 019-, 029)$ & ,029 (,024-,037) & $<0,001^{\mathrm{a}, \mathrm{b}}$ \\
\hline
\end{tabular}

a: CT+ vs control; b: CT- vs control; c: CT + vs CT - 
Table 3. Comparison of CBC markers regarding to trauma severity and AIS score

\begin{tabular}{|c|c|c|c|c|c|c|}
\hline & $\begin{array}{l}\text { Sever trauma }+ \\
\quad(\text { min-max })\end{array}$ & $\begin{array}{l}\text { Sever trauma } \\
-(\min -\max )\end{array}$ & $\mathbf{p}$ & AIS $<2$ & AIS $\geq \mathbf{2}$ & $\mathbf{p}$ \\
\hline WBC (/I) & $13.9(10.7-22.9)$ & $10.5(8.60-12.4)$ & .020 & $9.8(8.3-12.9)$ & $18.2(10.4-23.7)$ & .007 \\
\hline Neu $(/ \mathrm{I})$ & $9.9(6.4-16)$ & $4.7(3.2-6.9)$ & $<0.001$ & $4.8(3.1-7.5)$ & $14.7(6.1-16.9)$ & .002 \\
\hline Plt $\left(\mathrm{x} 10-{ }^{3}\right)$ & $354(290-388)$ & $303(246-383)$ & .193 & & & \\
\hline Pct & $.27(.24-.29)$ & $.23(.20-.28)$ & .069 & $.23(.20-.28)$ & $.25(.17-.27)$ & NS \\
\hline PDW & $16.4(16.3-16.5)$ & $16.4(16.2-16.8)$ & .840 & & & \\
\hline MPV (fl) & $8(7.05-8.40)$ & $7.6(7.20-8.20)$ & .592 & $7.80(7.50-8.45)$ & $7.65(6.97-6.97)$ & NS \\
\hline $\mathrm{MPV} / \mathrm{W}$ & $.57(.30-.78)$ & $.73(.61-.87)$ & .020 & $.78(.62-.91)$ & $.45(.30-.77)$ & .016 \\
\hline $\mathrm{MPV} / \mathrm{N}$ & $.81(.42-1.28)$ & $1.52(1.11-2.31)$ & $<0.001$ & $1.51(1.10-2.60)$ & $.56(.42-1.27)$ & .005 \\
\hline
\end{tabular}

$-0.335 ; \mathrm{p}<0.05$ ) (Figure 1b, $1 \mathrm{~d}$ ). By contrast, a positive correlation was observed between the AIS score and WBC $(r=0.316 ; \mathrm{p}<0.05)$ and the AIS score and Neu $(\mathrm{r}$

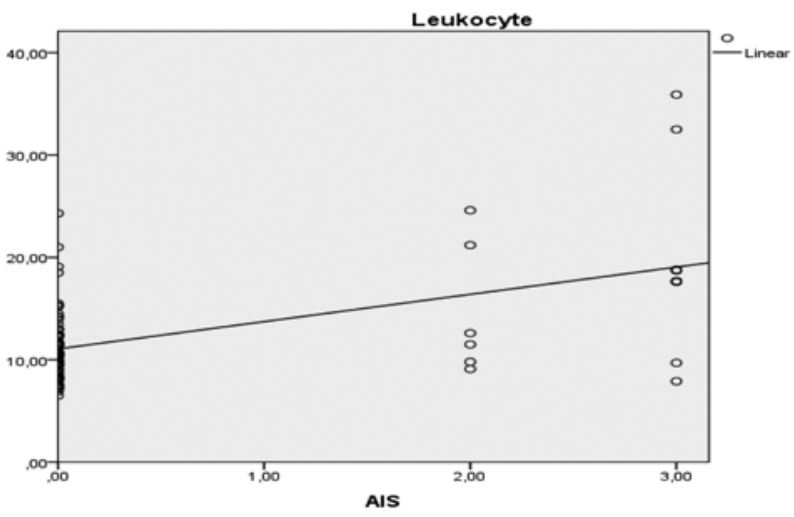

Figure 1a: Correlation graph between $W B C$ and AIS score

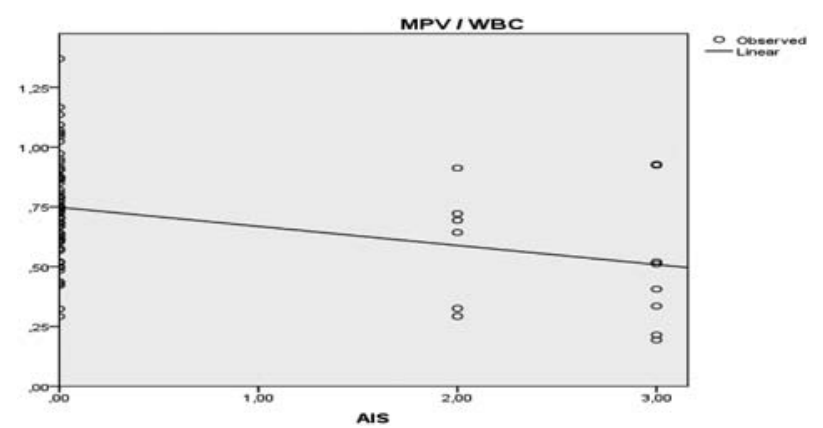

Figure 1b: Correlation graph between $M P V / W$ and AIS score

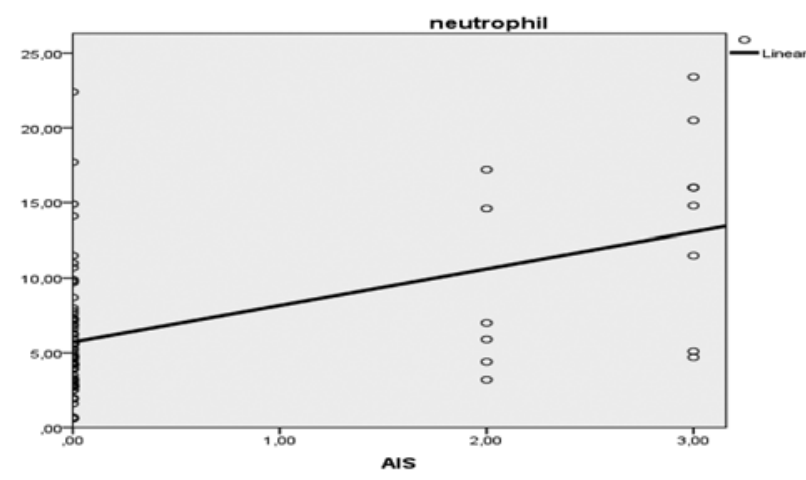

Figure 1c: Correlation graph between Neutrophil and AIS score $(p<0.05, r=, 365)$

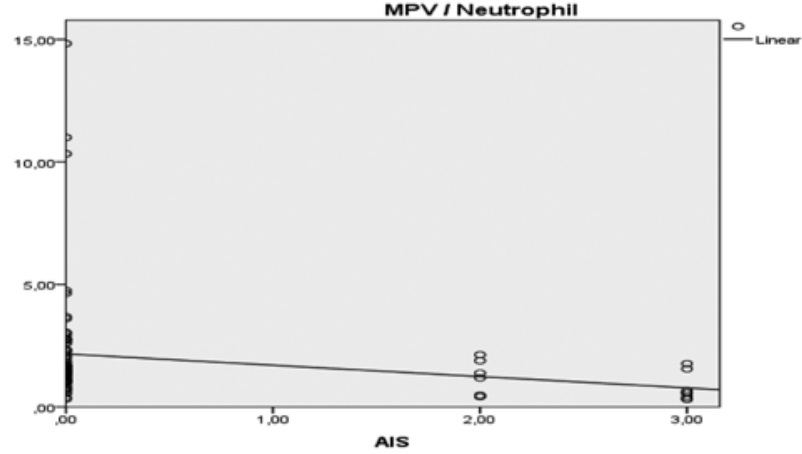

Figure 1d: Correlation graph between $M P V / N$ and AIS score

$=0.365 ; \mathrm{p}<0.05)$ (Figure 1a, 1c). Neu and MPV/N exhibited area under the curve (AUC) values of 0.805 (95\% confidence interval [CI], 0.70-0.88; p] and 0.782 (95\% CI, 0.68-0.86; p) respectively for differentiating patients with MHT and severe trauma from those with no severe trauma (Figure $2 \mathrm{a}$ ). Setting the WBC cut-off value to $>18.5$ and the MPV/W cut-off value to $\leq 0.41$ gave $99.33 \%$ and $94.67 \%$ specificity, respectively, for differentiating MHT patients with AIS scores $>1$ from

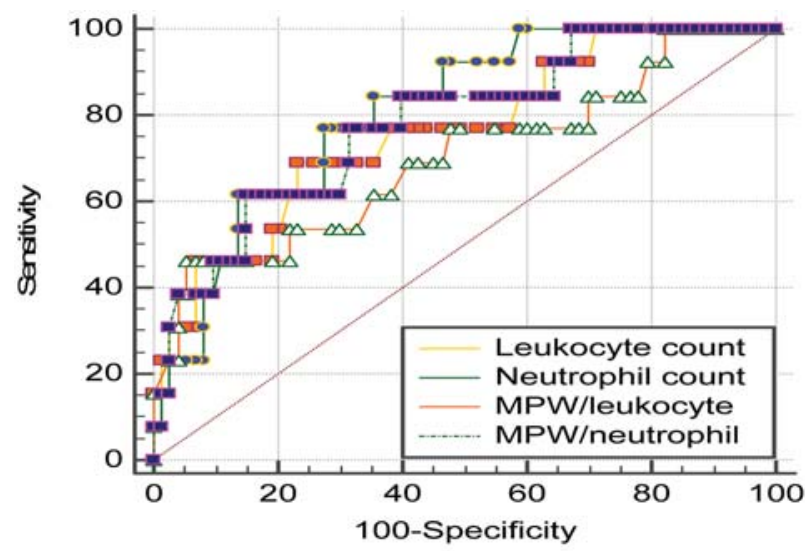

\begin{tabular}{|lllllll|}
\hline Variable & AUC & SE $^{*}$ & $95 \% \mathrm{Cl}^{3}$ & Cut-off & sensitivity & specifity \\
\hline WBC & 0,761 & 0,0753 & 0,657 to $0,847>12.5$ & 69.23 & 76.21 \\
Neu & 0,805 & 0,0585 & 0,705 to $0,883>6.9$ & 76.92 & 72.60 \\
\hline MPW/W & 0,701 & 0,0902 & 0,592 to 0,795 & 50.41 & 46.15 & 94.52 \\
MPW/N & 0,782 & 0,0701 & 0,680 to $0,86450.9$ & 61.54 & 84.93
\end{tabular}

Figure 2a: The ROC curves of variables for the presence of severe trauma 


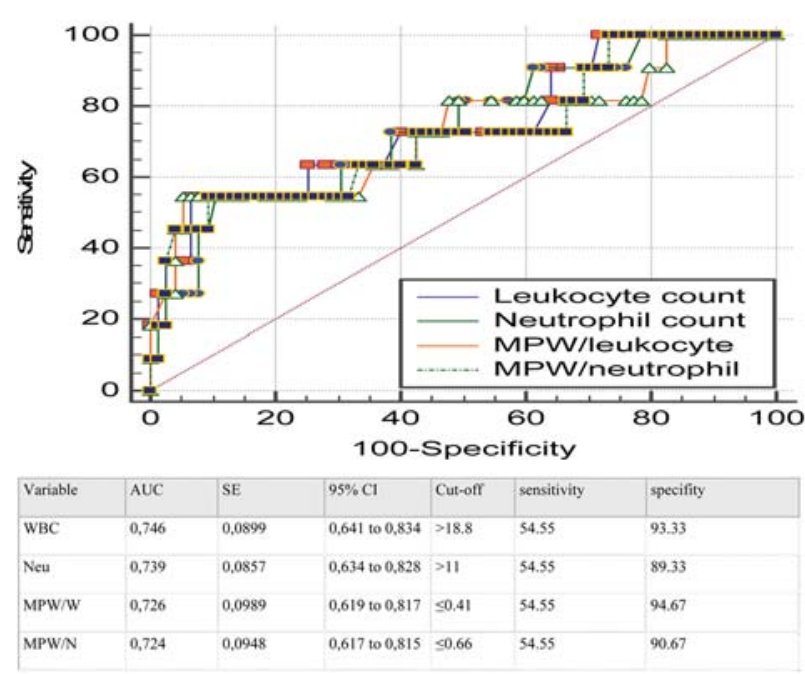

Figure 2b: The ROC curves of varibales for AIS $>1$

those with AIS scores $<1$ (Figure $2 b$ ). When differentiating the patients who had clinically severe trauma from patients who do not, setting the MPV/W cut-off value to $\leq 0.41$ gave a specificity of $94.52 \%$ (Figure 2a).

\section{DISCUSSION}

This study demonstrated that WBC and Neu levels in children with MHT were significantly higher than those in healthy controls. Furthermore, a progressive increase in WBC and Neu levels occurred in parallel with the presence of head CT pathologies. The elevated levels of WBC, particularly Neu in children with MHT, indicated a post-traumatic inflammatory response $(11,14,15,16)$. It was clear from our sample that WBC and Neu levels were significantly higher in the head CT-negative MHT group than the healthy controls. This result suggests that the stress of trauma itself can result in marked demargination of leukocytes even in patients who do not sustain a significant injury. Furthermore, in the current study, WBC and Neu levels were positively correlated with trauma severity and the AIS score. Rovlias et al. reported that patients with a severe head injury have significantly higher WBC counts than those with moderate or MHT (14). In fact increased cortisol and catecholamine are responsible for the increase in the WBC count in patients with head trauma and patients with a higher WBC count on admission often have a poorer outcome $(14,17,18)$. Our study provides evidence for the involvement of WBC and Neu after MHT. In particular, Neu counts could provide additional information about trauma severity and the presence of brain pathologies on head CT scans in children with MHT. Nevertheless, the increased WBC and Neu counts alone in parallel with the presence of brain injury and clinically severe trauma may reflect the stress response.

Could PVI alone or in combination with WBC count be of diagnostic value for brain injury after MHT? MPV and PDW represent platelet size and are potential biomarkers of platelet activity. However, only MPV values appeared to be of significance in patients with MHT in our study. This finding is compatible with the literature that among all variables produced by complete blood count analyses, MPV is better and well-standardized than PDW $(19,20)$. An increase in the MPV value suggests an increased released of a larger number of hyperactive platelets from the spleen, whereas a decrease in the MPV value may be due to consumption of larger platelets which occurs in sepsis, high-grade systemic inflammatory diseases, and an acute attack of familial Mediterranean fever in children $(21,22,23)$. MPV values increase in some clinical situations such as cardiovascular disorders, stroke, and cancers $(8-10,24)$. The most important result of the current study was that within $24 \mathrm{~h}$ of injury MPV values decreased compared to healthy controls although there was no pathology on a head CT scan. Unlike the results of previous studies on head trauma, the decrease in MPV values was unexpected (11, 12). However, a similar finding was reported in a study of 54 adult patients with MHT (13). The results of that study also demonstrated that a progressive decrease in MPV occurs in parallel with the severity of MHT (13). A possible explanation could be the consumption of larger platelets at the site of leucocyte migration immediately after the trauma. An inverse relationship has been reported between platelet count and MPV under physiological and some pathological conditions to maintain haemostasis by preserving a constant platelet mass (25). We did not find any significant difference in the platelet count between the study and control groups. Although we cannot explain the pathology underlying the significant decrease in MPV with a normal platelet count, we believe that MHT without a brain injury would have a different effect on platelet biology, as physical damage may result in a higher prevalence of hypo reactive platelets than that in patients in other clinical situations (8-10, 24, 26). Our results also did not show any differences in MPV levels regarding trauma severity or the AIS score. However, if we investigated serial MPV measures in our study, we would have a better idea about the balance between selective consumption of larger platelets and the ability of the bone marrow to replace platelets in patients with acute isolated MHT.

When we examined the ratio of parameters that increased and decreased within $24 \mathrm{~h}$ after MHT, the results showed that the MPV/W, MPV/N, MPV/PL ratios of the study groups significantly decreased compared to the healthy blood donors. Moreover, the MPV/W and MPV/N ratios were significantly lower in patients with head CT pathologies than in those with a normal head CT scan.

The results of our study have some clinical implications. This study provides evidence for the involvement of WBC, Neu, and MPV within $24 \mathrm{~h}$ following 
MHT. Although many markers have been studied and defined, CBC is easily accessible and inexpensive to perform in clinical practice. The MPV/W and MPV/N ratios provided additional information about trauma severity in children with isolated MHT and may be useful for patients with MHT who are being observed for possible traumatic brain injury.

Some limitations of our study should be mentioned. The study sample was small, and we did not conduct a serial $\mathrm{CBC}$ count for the patients. If serial $\mathrm{CBCs}$ were assessed, then possible changes in MPV and platelet count and the balance between thrombopoiesis and inflammation in patients with severe trauma after MHT would have been clearly revealed.

We suggest that the diagnostic performance of the $\mathrm{MPV} / \mathrm{N}$ ratio for identifying clinically severe trauma in children with MHT (i.e., AUC of 0.78 ; $p=0.01$ ) with sensitivity and specificity of 0.61 and 0.84 , respectively for values $<0.9$ provides a reliable basis for planning further investigations.

\section{CONCLUSION}

The MPV/W and MPV/N ratios can be used as markers for the severity of injury in patients with MHT presenting to the paediatric emergency room when the necessity for a head CT scan is unclear.

\section{Acknowledgement}

The English in this document has been checked by at least two professional editors, both native speakers of English (18041804). This article presented orally on 5th Intercontinental Critical Care and Emergency Medicine Congress in Antalya, Turkey, 19 April 2018.

\section{Acknowledgements and authorship}

Emel Ataş Berksoy and Murat Anıl were involved in the conception and design of the study, and analysis and interpretation of data. Murat Anıl and Emel Ataş Berksoy drafted the article or revised it critically for important intellectual content. All authors approved the final version to be submitted. We thank Dr Gamze Gökalp and Dr Yüksel Bıcılığlu for their help with data collection.

\section{Declaration of conflicting interests}

The authors declare that the manuscript has not been submitted to more than one journal for simultaneous consideration. The authors declare that the manuscript has not been published previously

\section{Funding}

The author(s) received no financial support for the research, authorship, and/or publication of this article.

\section{Availability of data and materials}

The authors declare that no data have been fabricated or manipulated (including images) to support your conclusions. The authors declare that no data, text, or theories by others are presented as if they were the authors own.

\section{Informed consent}

Written informed consent was not necessary because no patient data has been included in the manuscript.

\section{Human rights}

All procedures performed in studies involving human participants were in accordance with the ethical standards of the institutional and/or national research committee and with the 1964 Helsinki Declaration and its later amendments or comparable ethical standards.

\section{Ethical approval}

We confirm that Ethical Committee approval was sought where necessary and is acknowledged within the text of the submitted manuscript.

\section{Licensing}

This work is licensed under a Creative Commons Attribution 4.0 International (CC BY 4.0) License.

\title{
Sažetak
}

\section{EFIKASNOST PARAMETARA KOMPLETNE KRVNE SLIKE ZA PREDVIĐANJE INTRAKRANIJALNE POVREDE KOD DECE SA MANJIM TRAUMAMA GLAVE}

\author{
Berksoy Atas Emel, Anıl Murat
}

Health Science University, Tepecik Education and training Hospital, Pediatric Emergency Clinic, İzmir, Turkey

Cilj: Cilj nam je bio da istražimo odnos između težine traume i broja trombocita (PI) i leukocita (WBC) za identifikaciju traumatske povrede mozga (TBI) kod dece sa manjim traumama glave (MHT).
Materijal i metode: Ova prospektivna studija obuhvatila je decu sa akutnim traumama glave koja su podvrgnuta kompjuterskoj tomografiji glave (CT) na osnovu kriterijuma Pedijatrijske istraživačke mreže hit- 
ne pomoći (PECARN). Evaluirane su vrednosti srednjeg volumena trombocita (MPV), širina raspodele trombocita (PDW), odnos srednjeg volumena trombocita i trombocita (MPV/PL), odnos srednjeg volumena trombocita i leukocita (MPV/WBC), kao i odnos srednjeg volumena trombocita i neutrofila (MPV/Neu).

Rezultat: 86 dece sa MHT i 245 kontrola su uključeni u studiju. WBC, broj neutrofila, MPV, MPV/WBC, MPV/Neu kao i MPV/PI razmere bile su statistički drugačije kod pacijenata sa abnormalnim tomografijama glave,

\section{REFERENCES}

1. Faul M XL, Wald MM, Coronado VG. Traumatic Brain Injury in the United States: Emergency Department Visits, Hospitalizations, and Deaths. Atlanta, GA: US Centers for Disease Control and Prevention, National Center for Injury Prevention and Control. 2010.

2. Kuppermann N, Holmes JF, Dayan PS, Hoyle JD, Atabaki SM, Holubkov R et al. Pediatric Emergency Care Applied Research Network (PECARN). Identification of children at very low risk of clinically important brain injuries after head trauma: a prospective cohort study. Lancet. 2009; 374(9696): 1160-70.

3. De Long Jr. WG, Burn CT. Cytokines in patients with polytrauma. Clin Orthop Relat Res 2004; 422: 57-5.

4. Sandhause LM, Meyer P. How useful are CBC and reticulocyte reports to clinicians? Am J Clin Pathol. 2002; 118(5) 787-93.

5. Schnuriger B, Inaba K, Abdelsayed GA, Lustenberger T, Eberle BM, Barmparas G, et al. The impact of platelets on the progression of traumatic intracranial hemorrhage. J Trauma. 2010; 68(4): 881-5.

6. Nekludov M, Bellander BM, Blombäck M, Wallen HN.Platelet dysfunction in patients with severe traumatic brain injury. J Neurotrauma. 2007; 24(11): 1699-706.

7. Van der Loo B, Martin JF. A role for changes in platelet production in the cause of acute coronary syndromes. Arterioscler Thromb Vasc Biol. 1999; 19(3): 672-9.

8. Aksoy S, Kilickap S, Hayran M, Harputluoglu H, Koca E, Dede DS, et al. Platelet size has diagnostic predictive value for bone marrow metastasis in patients with solid tumors. Int J Lab Hematol. 2008; 30: 214-9.

9. Lippi G, Mattiuzzi C, Comelli I, Cervellin G. Mean platelet volume in patients with ischemic heart disease: Meta-analysis of diagnostic studies. Blood Coagul Fibrinolysis 2013; 24(2): 216-9.

10. Cay N, Ipek A, Gumus M, Birkan Z, Ozmen E. Platelet activity indices in patients with deep vein thrombosis. Clin Appl Thromb Hemost. 2012; 18(2): 206-10.

11. Acar E, Demir A, Alatas ÖD, Beydilli H, Yıldırım B, Kırlı U et al. Evaluation of hematological markers in minor head trauma in the emergency room. Eur J Trauma Emerg Surg. 2016; 42(5): 611-6.

12. Yolcu S, Beceren GN, Tomruk Ö, Doguç DK, Balbaloglu O. Can mean platelet volume levels of trauma patients predict severity of trauma? Platelets. 2014; 25(4): 279-84. kod pacijenata sa normalniom tomografijama i u kontrolnoj grupi $(\mathrm{p}<0.05)$. Za predviđanje skraćene ocene povrede (AIS) > 1, AUC vrednosti WBC-a, neutrofila, MPV/WBC i MPV/Neu bile su 0.746, 0.739, 0.726 i 0.724.

Zaključak: Kod dece sa MHT koja su podvrgnuta CT snimanju, WBC, Neu, MPV/WBC i MPV/Neu mogu biti korisni za predviđanje ozbiljnosti traume u pedijatrijskom odeljenju hitne službe.

Ključne reči: deca, kompletna krvna slika, povrede glave, intrakranijalna povreda.

13. Lippi G, Carbucicchio A, Benatti M, Cervellin G. The mean platelet volume is decreased in patients with mild head trauma and brain injury. Blood Coagul Fibrinolysis. 2013; 24(7): 780-3.

14. Rovlias A, Kotsou S. The Blood Leucocyte count and its prognostic significance in severe head injury. Surg Neurol 2001; 55(4): 190-6.

15. Gürkanlar D, Lakadamyalı H, Ergun T, Yilmaz C, Yücel E, Altinörs N. Predictive value of Leukocytosis in Head Trauma. Turk Neurosurg. 2009; 19(3): 211-5.

16. Keskil S, Baykaner MK, Ceviker N, Ceviker N, Aykol Ş. Head trauma and leucocytosis. Acta Neurochir (Wien). 1994; 131(3-4): 211-4.

17. Pentelenyi T. Significance of endocrine studies in the general assessment and prediction of fatal outcome in head injury. Acta Neurochir Suppl (Wien). 1992; 55: 21-4.

18. Rosner MJ, Newsome HH, Becker DP. Mechanical brain injury: The sympathoadrenal response. J Neurosurg. 1984; 61(1): 76-86.

19. Beyan C, Kaptan K, Ifran A. Platelet count, mean platelet volume, platelet distribution width, and plateletcrit do not correlate with optical platelet aggregation responses in healthy volunteers. J Thromb Thrombolysis. 2006; 22(3): 161-4.

20. Cooke J, Murphy T, McFadden E, O'Reilly M, Cahill MR. Can mean platelet component be used as an index of platelet activity in stable coronary artery disease? Hematology. 2009; 14(2): 111-4.

21. Robbins G, Barnard DL. Mean platelet volume changes in infection. J Clin Pathol. 1983; 36(11): 1320.

22. Kisacik B, Tufan A, Kalyoncu U, Karadag O, Akdogan A, Ozturk MA, et al. Mean platelet volume (MPV) as an inflammatory marker in ankylosing spondylitis and rheumatoid arthritis. Joint Bone Spine. 2008; 75(3): 291-4.

23. Makay B, Türkyilmaz Z, Unsal E. Mean platelet volume in children with familial Mediterranean fever. Clin Rheumatol. 2009 ; 28(8): 975-8.

24. Turfan M, Erdogan E, Ertas G, Duran M, Murat SN, Celik E, et al. Usefulness of mean platelet volume for predicting stroke risk in atrial fibrillation patients. Blood Coagul Fibrinolysis. 2013; 24(1): 55-8.

25. Thompson CB. From precursor to product: How do megakaryocytes produce platelets? Prog Clin Biol Res. 1986; 215: 361-71.

26. Lippi G, Salvagno GL, Targher G, Guidi GC. Relationship between mean platelet volume and biochemical components of the metabolic syndrome. Clin Drug Investig. 2007; 27(10): 731-2.

\section{Correspondence to/Autor za korespondenciju}

Emel Ataş Berksoy

Health Science University, Tepecik Education and Training Hospital, Pediatric Emergency Clinic, Yenişehir, Konak, 35170, İzmir, TURKEY email: emelberksoy@hotmail.com 